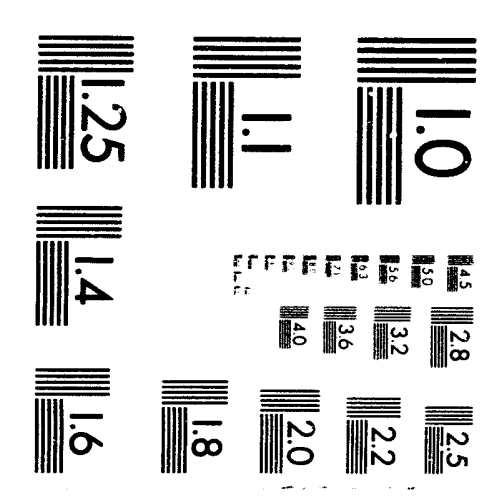



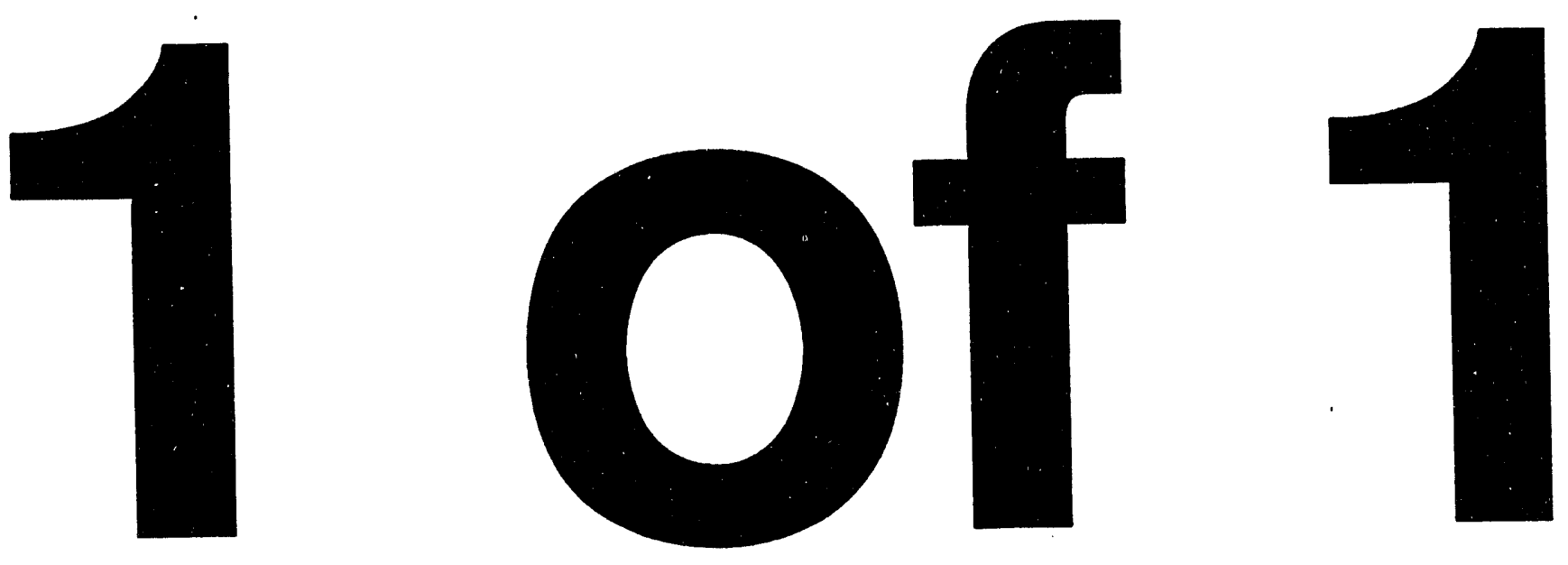


\title{
Safety Analysis Factors for Environmental Restoration and Decontamination and Decommissioning
}

\author{
D. R. Ellingson
}

Date Published

April 1993

To Be Presented at ER/D\&D Subgroup Meeting Denver, Colorado June 14-18, 1993

Prepared for the Environmental Restoration and Decontamination and Decommissioning (ER/D\&D) Subgroup under the Sponsorship of the Energy Facility Contractors Group (EFCOG) Safety Analysis Working Group (SAWG)

\section{(2) Westinghouse $\begin{aligned} & \text { P.O. Box } 1970 \\ & \text { Hanford Company }\end{aligned}$}

Hanford Operations and Engineering Contractor for the

U.S. Department of Energy under Contract DE-AC06-87RL10930

Copyright License By accoptance of this article, the publisher and/of rocipient acknowlodges the U.S. Government's right to rotain a nonexclusive, royahy-troe license in and to any copyright covering this paper.

Approved for Public Release 
WHC-SA-1917-FP

CONTENTS

1.0 INTRODUCTION . . . . . . . . . . . . . . . . . . . . . . . 1

2.0 ISSUE BACKGROUND ........................... 1

3.0 CLEANUP DESIGN SUMMARY . . . . . . . . . . . . . . . . . . 2

4.0 CLEANUP DESIGN REQUIREMENTS REVIEW . . . . . . . . . . . . . . . 2

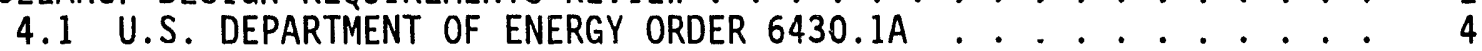

4.2 U.S. DEPARTMENT OF ENERGY ORDER $5820.2 A$. . . . . . . . . . . 5

4.3 NUCLEAR REGULATORY COMMISSION GUIDANCE . . . . . . . . . . 5

4.4 SPECIFIC CONDITIONS . . . . . . . . . . . . . . . . 5

5.0 SAFETY REQUIREMENTS ........................... 6

6.0 CLEANUP OBJECTIVES AND OPERATIONS . . . . . . . . . . . . . . . 7

7.0 CLEANUP DESIGN APPROACH, CONSIDERATIONS, AND METHODS . . . . . . . 9

7.1 INTRODUCTION ...................... 9

7.2 GENERAL APPROACH .................... . . 9

7.3 HAZARD REDUCTION ...................... 9

7.4 HAZARD MITIGATION DESIGN . . . . . . . . . . . . . . . 10

7.4.1 Criticality Prevention . . . . . . . . . . . . 10

7.4.2 Electrical Power................. . 11

7.4.3 Confinement .................. 11

7.4.4 Radiation Shielding .............. 12

7.4.5 Civil Structural................. 12

7.4.6 Administrative Controls . . . . . . . . . . . . . 13

8.0 DESIGN SUMMARY . . . . . . . . . . . . . . . . . . 13

9.0 PROPOSAL FOR SHORT-TERM PROJECTS . . . . . . . . . . . . . . 13

10.0 REFERENCES ....................... 14

\section{TABLES}

1 Safety Performance Objectives . . . . . . . . . . . . . . . . 3

2 Differences; New Construction, Modification, and Environmental

Restoration and Decontamination and Decommissioning . . . . . . . . 3

\section{FIGURES}

1. General Reduction in Hazards as the Operation Proceeds . . . . . . 8

2 Safety Controls Commensurate with Hazards . . . . . . . . . . . . . 8 
WHC-SA-1917-FP

\section{SAFETY ANALYSIS FACTORS FOR ENVIRONMENTAL RESTORATION AND DECONTAMINATION AND DECOMMISSIONING}

\subsection{INTRODUCTION}

Environmental restoration (ER) and facility decontamination/ decommissioning (D\&D) operations can be grouped into two general categories. "Nonstationary cleanup" or simply "cleanup" activities are where the operation must relocate to the site of new contaminated material at the completion of each task (i.e., the operation moves to the contaminated material). "Stationary production" or simply "production" activities are where the contaminated material is moved to a centralized location (i.e., the contaminated material is moved to the operation) for analysis, sorting, treatment, storage, and disposal. This paper addresses the issue of nonstationary cleanup design. The following are the specific assigned action items:

- Collect and compile a list of special safety-related ER/D\&D design factors, especially ones that don't follow DOE Order 6430.1A requirements.

- Develop proposal of what makes sense to recommend to designers; especially consider recommendations for short-term projects.

- Present proposal at the January meeting.

To achieve the action items, applicable U.S. Department of Energy (DOE) design requirements, and cleanup operations and differences from production activities are reviewed and summarized; basic safety requirements influencing design are summarized; and finally, approaches, considerations, and methods for safe, cost-effective design of cleanup activities are discussed.

\subsection{ISSUE BACKGROUND}

The previous defense portion of the DOE mission is undergoing an evolutionary change. The mission evolution increases the focus on cleanup of contaminated soil sites (ER) and retired facilities (D\&D). The evolutionary change includes an increase in cost consciousness and maintains the high standards of operational safety. To meet these evolutionary challenges, DOE contractors have formed the Energy Facility Contractors Group (EFCOG). The EFCOG has established advisory committees, subcommittees, and working groups to develop information according to the various disciplines and specialties. The Environmental Restoration and Decontamination and Decommissioning subgroup was formed under the safety analysis discipline to identify and develop information needed to meet the increased focus on cleanup. Issues have been identified and discussed at subgroup meetings. The issue of ER/D\&D design is one of the identified items selected for priority development. 
WHC-SA-1917-FP

\subsection{CLEANUP DESIGN SUMMARY}

Design criteria, codes, and standards are the result of experience, improvements, and consensus developed over time of "what works" for a specific application. Cleanup activities are relatively new to the DOE community, especially when the regulatory dynamics currently being applied are considered. Although specific criteria for cleanup design have not been developed, philosophies, approaches, and methods can be developed and discussed. When combined with shared experiences, the time required to develop and reach agreement on cleanup design criteria and guidance will be shortened.

Cleanup activities differ in operational requirements from production activities. Production activities are generaily conducted in "campaigns" over discrete intervals of time. The production activities have process flow sheets defining the introduction and the processing of material within the facility. Each successive campaign is bounded and controlled by the hazard analysis/safety analysis that is based on the flow sheet. Based on the known and reoccurring conditions, the design of production facilities provided fixed systems inside stationary structures, centrally $1 r$ ated and capable of withstanding accident conditions while continuing to function over many campaigns.

When individual cleanup tasks (either ER or D\&D) are compared to a production campaign, the operational demand differences placed on design become apparent. Cleanup activities must "deal with" whatever material is found at the site; i.e., the material is not controlled by a process flow sheet. As the cleanup operation progresses, the contaminated material inventory (hazard) decreases; i.e., the margin of safety increases with time; and safety design demands are not constant. At the completion of each task (campaign), the entire operation moves to the next site or facility; i.e., the operation is not stationary from campaign to campaign. These differences require the successful cleanup design to move from fixed systems and stationary structures to reusable, mobile, modular designs that are flexible and tolerant of conditions and material discovered to actually exist during the operation. The safety similarities and differences are summarized in Tables 1 and 2 , respectively.

\subsection{CLEANUP DESIGN REQUIREMENTS REVIEW}

Most of the design requirements for DOE facilities and activities are contained in DOE Order 6430.1A, General Desigri Criteria (DOE 1989).

Additional design requirements are also provided in DOE Orders 5400.5,

Radiation Protection of the Public and Environment (DOE 1988a); 5480.5, Safeiy of Nuclear Facilities (DOE 1986); 5480.11, Radiation Protection for Occupational Workers (DOE 1988b); and 5820.2A, Radioactive Waste Management (DOE 1988c). Some of the U.S. Nuclear Regulatory Commission (NRC) guidance for cleanup is also reviewed to add perspective. 
WHC-SA-1917-FP

Table 1. Safety Performance Objectives.

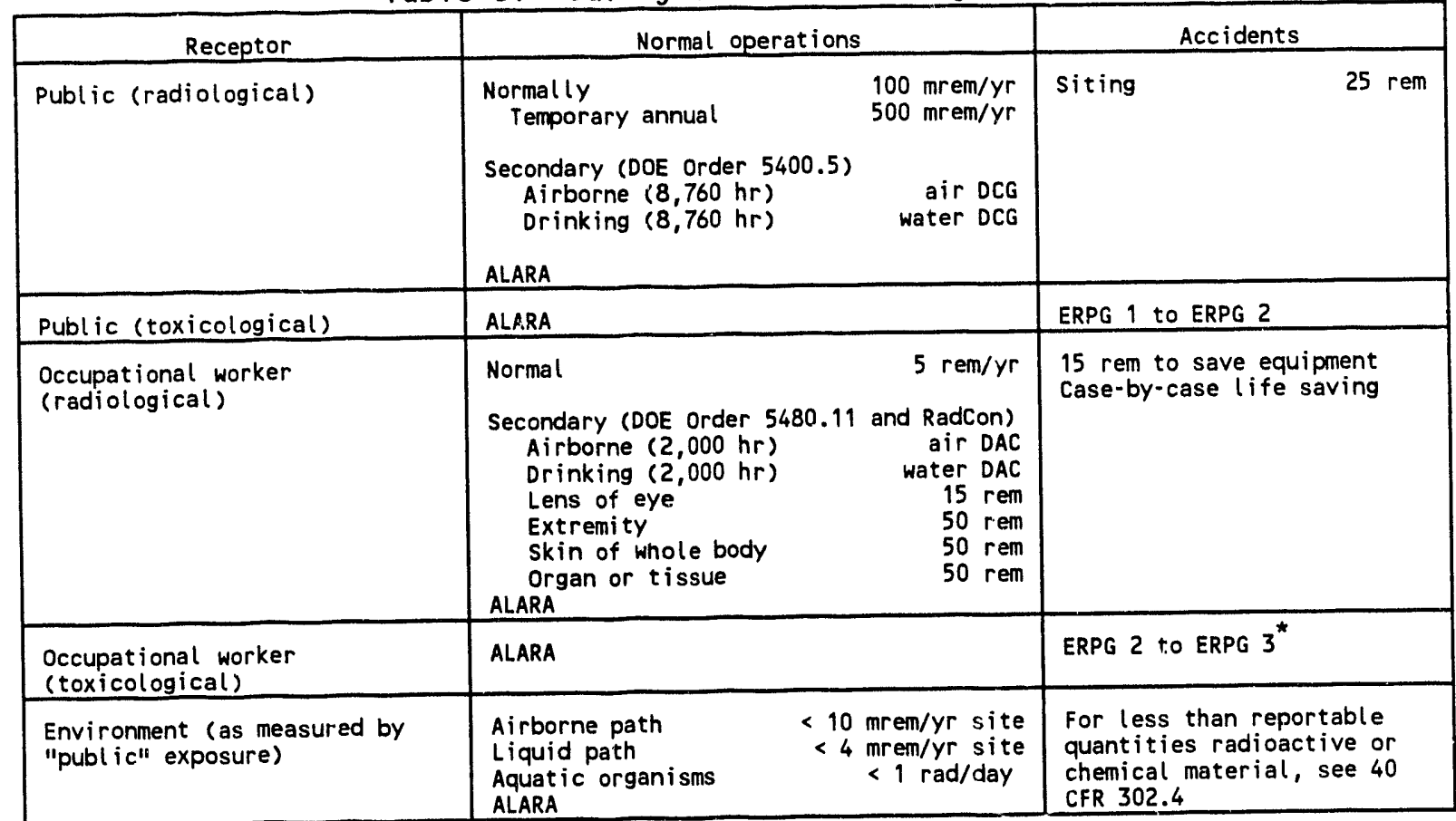

*Additional information on toxicological releases is provided in Toxic Chemical Hazard Classification and Risk Acceptance Guidel ines for Use in DOE Facilities (Craig et al. 1993).

ALARA = as low as reasonably achievable.

$D A C=$ derived air concentration.

$D C G=$ derived concentration guide.

ERPG = Emergency Response Planning Guidel ines.

Table 2. Differences; New Construction, Modification, and Environmental Restoration and Decontamination and Decommissioning.

\begin{tabular}{|c|c|c|c|}
\hline Item & New construction & Modification & ER/D\&D \\
\hline Hazard & $\begin{array}{l}\text { Introduces new hazard to the site } \\
\text { or complex }\end{array}$ & $\begin{array}{l}\text { Introduces new or alters } \\
\text { existing hazard in the } \\
\text { facility }\end{array}$ & $\begin{array}{l}\text { Removes, reduces, or } \\
\text { mitigates existing hazard }\end{array}$ \\
\hline $\begin{array}{l}\text { Hazard } \\
\text { level }\end{array}$ & $\begin{array}{l}\text { "Bounding" hazard level is } \\
\text { constant (stable) }\end{array}$ & $\begin{array}{l}\text { New "bounding" level is } \\
\text { constant (stable) }\end{array}$ & $\begin{array}{l}\text { Level generally constantly } \\
\text { decreasing as operation } \\
\text { progresses }\end{array}$ \\
\hline Duration & 50- to $100-y r$ design life & $\begin{array}{l}\text { Mission design life; varies } \\
\text { generally } 10 \text { to } 50 \mathrm{yr}\end{array}$ & $\begin{array}{l}\text { Months to a few years ( } 1 \text { to } \\
5 \mathrm{yr} \text { ) }\end{array}$ \\
\hline Inventory & $\begin{array}{l}\text { Flow sheet known, part of design } \\
\text { information }\end{array}$ & $\begin{array}{l}\text { Flow sheet known, design } \\
\text { and/or operating information }\end{array}$ & $\begin{array}{l}\text { Inventory uncertain, based on } \\
\text { historical reports and } \\
\text { remembrances (basically a } \\
\text { constant USQ evolution must } \\
\text { respond to what is found) }\end{array}$ \\
\hline objective & $\begin{array}{l}\text { Produce some product while } \\
\text { minimizing risk }\end{array}$ & $\begin{array}{l}\text { Mission change (new product) } \\
\text { or efficiency increase; } \\
\text { cont inue to minimize risk }\end{array}$ & $\begin{array}{l}\text { Make facility "go away" while } \\
\text { maintaining acceptable low } \\
\text { risk in the cleanup process }\end{array}$ \\
\hline siting & $\begin{array}{l}\text { Open within the boundaries of the } \\
\text { DOE reservation; generally sited } \\
\text { near other facilities having } \\
\text { similar missions or providing } \\
\text { necessary services; safety } \\
\text { considerations included in siting }\end{array}$ & $\begin{array}{l}\text { Limited choice; siting may } \\
\text { influence whether or not the } \\
\text { modification is authorized, } \\
\text { especially for mission } \\
\text { change modifications }\end{array}$ & $\begin{array}{l}\text { No choice; cleanup activity } \\
\text { does not have an option in } \\
\text { work location. Generally, the } \\
\text { higher the hazard because of } \\
\text { siting (proximity to public } \\
\text { or ground/surface water), the } \\
\text { more emphasis to cleanup }\end{array}$ \\
\hline
\end{tabular}

DOE $=$ U.S. Department of Energy.

ER/D\&D = Environmental Restoration/Decontamination and Decommissioning.

USQ = unreviewed safety question. 
WHC-SA-1917-FP

Neither the DOE orders nor the NRC guidance contains specific design criteria for cleanup activities. Some general guidance is provided for D\&D activities. Design guidance for ER activities is limited to referencing U.S. Environmental Protection Agency (EPA) guidelines. The DOE, NRC, and EPA recognize the wide variety of conditions and factors that need to be considered during final cleanup operations. The guidance relies on "the design professional" to develop features and controls to achieve safety performance objectives, put the specific design details developed into a "task specific plan," and submit the plan for review and approval. The DOE orders do contain specific design criteria cor "conditions" (e.g., criticality prevention and confinement), and where these conditions are needed for safe operation, the criteria should be applied. Summaries of the DOE and NRC guidance are provided in the following sections.

\subsection{U.S. DEPARTMENT OF ENERGY ORDER 6430.1A}

Sections 0205, "Demolition, Decontamination, and Decommissioning," and 1300-11, "Decontamination and Decommissioning," contain the majority of design guidance relating to the act of building cleanup. The remaining criteria relate to provisions for D\&D to be included during the design phase of new construction or major modification projects. Design for soil cleanup is not discussed in DOE Order 6430.1A (DOE 1989).

Section 0205, paragraph 0205-1, "Demolition," requires the design professional to develop a plan describing (1) the use of explosives, (2) the extent of demolition, (3) the methods for handling and disposing of hazardous materials, (4) salvage, and (5) backfilling. Paragraph 0205-2, "Decontamination and Decommissioning," discusses "provisions" to be included in facilities to aid in "ultimate facility decommissioning and disposal or reuse." Paragraph 0205-2 refers the reader to Section 1300-11.

Section 1300-11.1, "Decontamination," discusses "provisions" to be included in new designs "to simplify future decontamination."

Section 1300-11.2, "Decommissioning," refers the reader to the program requirements of DOE Order 5820.2A (DOE 1988c) and requires consideration of the following design principles:

- Use of modular, separable confinements

- Use of localized liquid transfer systems

- Exhaust filtration near individual enclosures (minimize contaminated ductwork)

- Use of equipment that precludes accumulation of radioactive and hazardous material in inaccessible areas (inspection covers)

- Waste minimization and materials easily decontaminated

- Designs that ease cutup, dismantlement, removal, and packaging

- Use of modular radiation shielding 
WHC-SA-1917-FP

- Use of lifting lugs on large tanks and equipment

- Fully drainable piping systems.

\subsection{U.S. DEPARTMENT OF ENERGY ORDER 5820.2A}

Chapter 5, "Decommissioning of Radioactively Contaminated Facilities," contains objectives and goals for building cleanup that should be considered during design, operation, and post operation of facilities. The basic requirement is for the DOE field organizations to develop and document their programs to surveil, maintain, and decommission contaminated retired facilities. Plans for actual decommissioning are to consider the 2-year budget cycle to ensure adequate funding.

The majority of criteria contained in Chapter 5 requires the development of programs and plans. Included in the program requirements is the need for detailed characterization and records of "past operations" including facility designs, operational records, and occurrence reports. The program also requires review of alternative decommissioning plans under appropriate environmental statues including the National Environmental Policy Act of 1969 (NEPA), the Resource Conservation and Recovery Act of 1976 (RCRA), the Comprehensive Environmental Response, Compensation, and Liability Act of 1980 (CERCLA), and the Superfund Amendments and Reauthorization Act of 1986 (SARA).

Specific engineering designs are to be developed to ensure that DOE safety objectives are met; i.e., radiological protection, hazardous chemical and safety standards, maintenance of physical safety and security, and the reduction of potential public and environmental hazards. DOE Order 5820.2A (DOE 1988c) states: "The decommissioning project shall be conducted in accordance with guidance from Headquarters program offices and the Decommissioning Project Plan."

\subsection{NUCLEAR REGULATORY COMMISSION GUIDANCE}

Specific requirements for decommissioning licensed facilities are contained in 10 CFR parts 30,40 , and 70 . Although the se requirements are provided in the Code of Federal Regulations, more informative guidance is contained in the Regulatory Guides - the NUREGs, and the NUREG/committee reports. The guidance affirms the need for a "decommissioning plan" and provides format and content descriptions of what should be included in the plan. Emphasis is placed on providing designs that protect workers and the public from radiological exposure and contaminants and minimize releases to the environment. Other areas of emphasis include the timing of plan submittal (before liceilse termination) and financial responsibility.

\subsection{SPECIFIC CONDITIONS}

Criticality prevention and hazardous material confinement are two conditions that DOE orders provide design criteria for, regardless of the type of activity being conducted. Both conditions are safety performance objectives but are treated uniquely under the order review because they frequently reoccur in the orders. 
Criticality prevention design (e.g., DOE Orders 6430.1A, 5480.5, and $5480.11)$ is applied when there is the potential for fissile material in sufficient quantity and form (existing distribution or operationally caused redistribution/concentration) that a criticality may occur. Simply stated, if the condition coult possibly exist, apply the design criteria.

Confinement, and the need for confinement ventilation, is determined on a case-by-case basis. DOE Order 6430.1A, Section 1300-7.2, "Confinement Systems," states: "Engineering evaluations, trade-offs, and experience shall be used to develop a practical design that achieves confinement system objectives" (DOE 1989).

\subsection{SAFETY REQUIREMENTS}

This section addresses the radiological and toxicological safety criteria that influence design and are required to be addressed in the safety analysis. Other safety requirements such as Industrial Safety, Occupational Safety and Health Administration, and Fire Protection have criteria that influence design; however, these requirements generally are not covered in the safety analysis unless they initiate or increase the consequences of a nuclear incident.

There are only a few primary radiological criteria contained in the DOE orders that require mitigative design features. The following are these features:

- Double contingency to prevent accidental criticalities

- Public exposures from "normal" operations > $100 \mathrm{mrem} / \mathrm{yr}$ cumulative effective dose equivalent (CEDE)

- Environmental contamination giving the public $>4 \mathrm{mrem} / \mathrm{yr}$ from the drinking water pathway (normal operations)

- Environmental contamination giving the public >10 mrem/yr from the airborne pathway (normal operations)

- Siting a facility where potential public exposures exceed 25 rem CEDE from design basis accidents

- Worker exposures from "normal" operations > 5 rem/yr CEDE.

The primary radiological criteria give rise to numerous secondary and tertiary criteria including extremity and organ doses, derived concentration guide (DCG) (public) and derived air concentration (DAC) (worker).

Although the DOE has not formally endorsed toxicological release and exposure criteria for design, most DOE sites (contractors) are using the Emergency Response Planning Guidelines (ERPG) to influence and assess safety designs for the mitigation of potential toxicological releases. The following criteria are being used:

- Accident releases mitigated to ERPG 1 to ERPG 2 (depending on event frequency) for publi.c exposures 
WHC-SA-1917-FP

- Accident releases mitigated to ERPG 2 to ERPG 3 for worker exposures

- Consideration is required to be given to incremental cancer risks (ICR) of all chemical releases.

Note: Additional information on toxicological releases is provided in Craig et al. 1993.

Activities are also required to consider designs that reduce all releases and exposures to as low as reasonably achievable (ALARA).

Cleanup of retired or surplus structures and existing contaminated soil sites starts with the building or site in the "as is" condition. It is rare to find this condition compliant with current design criteria or having current regulatory requirement provisions for D\&D. It is not feasible or even desirable to bring these buildings into compliance with (backfit to) current design criteria before cleanup. However, upgrades or enhancements are warranted where they are needed to ensure cleanup can proceed safely (primary criteria). Radiological and toxicological safety requirements for defining safe operation are tabulated in Table 1.

\subsection{CLEANUP OBJECTIVES AND OPERATIONS}

All operations have the objective of conducting safe and efficient activities in a cost-effective and timely manner. Stationary production facilities achieve the safety objective with fixed protective features (e.g., air flow zoning, alarms, and shielding walls) arranged within the building to reduce risk. These features achieve the efficient objective with an

experience based building layout; i.e., known raw materials entry, designated process area, known product output. The cost-effective objective is achieved by ensuring the building and systems are constructed with sufficient rigor that they will survive accident challenges and continue to function through multiple campaigns. Contractors rely on specific design and construction codes and standards, and their experience in meeting "timely" objectives.

The long-term mission of both ER and building D\&D is to remove, reduce, and mitigate existing contaminants from soils or structures to a clean state or releasable for other uses. To achieve that mission, the operation must locate their activity to.a contaminated site, conduct the cleanup, and move to the next site. The duration of cleanup activities takes from a few weeks to a few years. The demolition of a stationary facility at the completion of each cleanup task and the start of construction at the next site would not lend itself to efficient, cost-effective or timely completion of the mission. Designs for portable and reusable features are needed to achieve operational objectives for cleanup activities. Some of the major differences among new construction, modifications, and cleanup activities are listed in Table 2. 
Another unique aspect of cleanup activities is a general reduction in the hazards as the operation proceeds (see Figure 1). Hazards consist of the material form and quantity, and the energy available to transport the material to people or the environment. As cleanup begins, the operation introduces energy not available when the site or building was in the shutdown state.

Therefore, the hazard may initially increase. The risk might also undergo an increase initially because of barrier removal, but it also decreases. As the operation proceeds, the quantity of material at the site or in the building is reduced, producing a decreasing trend in the hazard level until the clearidp is complete.

The slope and shape of the decrease depends on the work sequence; i.e., for nonuniform material distributions, the slope and shape would depend on when during the cleanup process the "higher" hazard material was removed. It is also possible for segmented operations to generate multiple curves - one for each segment and one for the overall site or building.

The decreasing trend in hazard levels provides the opportunity to define "stages of operation" based on the minimum safety features needed to ensure safety (see Fiyure 2). Where portable equipment is used, flexibility of operations will be improved by applying features where and when they are needed. Even where the hardware is retained in operation for ALARA purposes, there are advantages in defining stages. Backup equipment can be reassigned, management attention and focus can be graded and applied where it is most needed, and gradations for surveillances, training, etc., can be assigned. All of these actions assist in increasing the efficiency, cost effectiveness, and timeliness of operations while retaining the safety commensurate to the hazard.

There is an area of caution that needs to be considered when staging work. Work sequence influences the complexity of the operation. Increasing the number of tasks simultaneously occurring (even by different crews) within a given cleanup activity increases the potential that something will go wrong in one of the tasks, potentially affecting the workers of other ongoing tasks. The hazards involved with each task (singular and cumulative) determine the potential to impact (Figure 2).

The design barriers provide isolation/segregation of hazards, thus reducing the potential to impact. The caution is to ensure that segmenting and stages have fully considered the potential for accident promulgation from one segment or stage to another. 
WHC-SA-1917-FP

\subsection{CLEANUP DESIGN APPROACH, CONSIDERATIONS, AND METHODS}

\subsection{INTRODUCTION}

This paper addresses the issue of ER/D\&D design as it is influenced by safety analysis. The issue is treated in a general fashion as specific design influences generated by the safety analys is would apply only to the specific hazards they are intended to mitigate. Also, the operational approach (e.g., digging a hole with explosives or a shovel) and sequencing of ER/D\&D work (e.g., single task or multiple concurrent tasks; highest hazards el iminated during first, middle, or last part of operation) influence both the safety analysis and the design. For purposes of opening the discussion on design, the assumption is that hazards have been tentatively identified, the work approach and sequence has been established, and a design team has been formed.

\subsection{GENERAL. APPROACH}

The proposed approach begins with the operations (project) lead engineer and lead safety engineer documenting specific performance objectives according to their particular discipline. The objectives could include such areas as timing, cost, exposure control, confinement, worker protection, and ALARA issues. Safety and operations then review the specific work to identify methods that would eliminate or reduce the existing hazards by changing the form or selecting a work sequence or altering/eliminating energy sources while assuring the performance objectives are met. Each hazard reduction method or combination of methods needs to be balanced against the performance objectives to ensure the end result is a safe, efficient, and effective operation. When existing hazards have been eliminated or reduced to the highest extent possible, the safety and operations engineer(s) work with the designer to develop design barriers that will mitigate the consequences of hazards to acceptable levels while achieving the performance objectives.

Note: Each hazard reduction method would be included in the safety analysis. The "residual hazard" would provide the basis for design.

\subsection{HAZARD REDUCTION}

One of the major hazards of soil remediation activities is fugitive dust generation (airborne contaminants) created by the cleanup activity or wind action, or a combination of both. Large area sites can involve thousands of curies of radioactivity (total quantity) when summed over the total soil volume to be remediated (even though the concentration is microcuries or even nanocuries per gram). The pianning of contaminated soil site remediation activities can reduce the hazard by establishing a limit of inventory available for release. Dividing the contaminated site into segments reduces the area, thereby reducing the quantity of "contaminated dust" released per time unit. Wetting the contaminated soil during cleanup activities effectively alters the contaminant particle size, thus reducing fugitive dust generation. Conducting cleanup activities during periods of low wind also reduces dust generation and transport energy. The appropriate combination of methods to reduce the hazards should be considered before considering design barriers that would mitigate hazard consequences. 
Another type of ER activity is the exhumation of previously buried or otherwise disposed of waste material. Limiting the hazards associated with this activity can be as simple as limiting the amount of buried material removed at any one time. This will limit the contaminant inventory available for accidental release. The NEPA environmental decision to remediate contaminated burial sites (as opposed to the "do nothing" option) considers the total buried inventory, possible container failure, and leaching to groundwater or other public pathways. The ER safety analysis considers how to remediate safely, through operational safety analysis. During the remedial activity, the associated hazards can be altered by limiting the inventory available that could become involved in an accident.

Hazard reduction in D\&D operations (structure cleanup) can be accomplished using these same general concepts. Applying a fixative to loose surface contaminants will alter the form and decrease the dispersible fraction. Sequencing the operation to specific rooms or building areas (segmenting) will limit the operational inventory. Limiting the number of simultaneous segmented cleanup operations to decrease complexity and avoid compounding hazards also will decrease the potential hazard consequences. Removing significant sources of inventory early in the operation will limit the duration the hazard needs to be considered and limit the releases from subsequent common cause or propagation events.

\subsection{HAZARD MITIGATION DESIGN}

For cleanup activities, design criteria focus on mitigating hazard consequences that can not be reduced further or eliminated before starting the cleanup. The DOE design guidance provided for DOE cleanup activities is general for D\&D operations and virtually nonexistent for soil site remediation. Still, the basic safety objectives of protecting the workers, onsite employees, and the public apply and form the basis for designing c ntrol features to mitigate the potential hazard consequences. Control features such as shielding, confinement, structural integrity (where existing buildings are involved), criticality prevention, and alarm/warning devices will need to provide safety where and when it is needed, and then be relocated or disposed with consideration to waste minimization.

In making design decisions for cleanup activities, consideration needs to be given to the duration of the specific activity, the complexity of the activity, the hazard consequences, and what hardware will be salvaged for use at the next activity. - Costly designs and equipment may need to be provided, even for short duration activities, to ensure safe operation. To make these items cost effective, designs will need to include provisions to make the hardware portable (or at least easily salvageable). Designs may al so need to consider modular items with the capability to be installed with different modules to fit a particular application. The following sections address general considerations for safety conditions normally. found in safety analyses.

\subsubsection{Criticality Prevention}

Criticality prevention design criteria contained in the existing DOE orders should be followed for cleanup operations or any other activity. Most of the "design" effort for criticality prevention in cleanup operations will 
revolve around the waste management aspects, such as packaging of removed material. However, it is possible that some "processing" or sorting will be a necessary part of the cleanup activity. Gravity flow, siphon breaks, container geometry, and all the other design considerations should be included where appropriate in all designs involving fissile material in quantities greater than the theoretical minimum critical mass. Consideration should be given to increasing the safety margin for cleanup criticality prevention because of the large uncertainty generally occurring in specific inventory knowledge. These criteria do not preclude portable analys is laboratories or even designs for "small" processing (field screening and/or sorting) modules.

\subsubsection{Electrical Power}

Power or energy for cleanup operations needs to be designed to fit the particular activity situations. The conduct of cleanup work is generally the primary energy source generating an airborne condition. A power loss will result in work stoppage but may not result in an unacceptable release. Where loss of power could result in unacceptable releases, consideration should be given to backup power or redesign of the confinement system to include a passive confinement mode sufficient to reduce releases to acceptable levels when combined with work stoppage. Warning or alarm systems would need to be included to ensure work stoppage upon active ventilation loss.

\subsubsection{Confinement}

Confinement of hazardous particles can be achieved with systems varying from general ground cover (soil cleanup) to a complex structure with multistage ventilation (stationary cleanup "treatment" center). The confinement system needed for a specific cleanup activity must consider the work to be performed, the hazard, the complexity of the activity (multiple activities simultaneously conducted at a single location), energies available, and if the energies are present continuously or only during actual work (i.e., if work ceases, is the release potential still present?), the cleanup rate (hazard decrease rate), and several other factors.

General soil cleanup releases (dust) are usually chronic rather than acute. For this type of activity, wind and cleanup equipment movement provide the predominant energy sources leading to the airborne dispersion of contaminants. Confinement barriers designed to inhibit the generation of dust (wetting or fixatives) during operations and separate the energy from the contaminants (ground cover) during nonwork periods are amongst the simplest forms. These barriers are used where unmitigated releases for long durations would be near the margins of risk acceptance. They provide a margin of safety and an ALARA reduction factor.

Retrieval or recovery of buried waste has the potential for acute type releases. Accumulation of retrieved items and in some cases individual items can contain sufficient material to represent an accident hazard. Confinement for this type of activity can involve a vented overpack, portable hot cell, or a tent of plastic or metal construction with an associated ventilation system. Vented overpacks and hot cells provide confinement for the unusual or anticipated small percentage of packages that are uncharacteristic of the normal retrieved items. Tent confinement provides control where packages may have lost their integrity and pockets of contamination are possible or 
expected. Tents may al so be used as weather covers for normal operation and provide a confinement function only for accident conditions. The specific type of confinement used depends on the method of recovery, the type of hazard and the confidence in the knowledge of inventory and package condition.

The confinement system used during D\&D operations will be dependent on the condition of the existing building and ventilation system. It is possible that the existing structure and ventilation is adequate without change or upgrade. Where existing systems are judged to be inadequate, consideration should be given to enhancing the existing system with portable ventilation and tents within the building. The tents and ventilation would provide the active operation zoning function while the existing structure and ventilation continued to provide the shutdown condition confinement for the remainder of the building. Care in the accident analysis and design is needed to ensure that credible accidents will not propagate beyond the work zone and lead to unacceptable consequences.

\subsubsection{Radiation Shielding}

Shielding design in cleanup activities relies on specific source reduction rather than general shielding walls used in process operations. Design related to portable shielding is limited to the material (high $z$ or low z), thickness, and features to make the shielding material easy to decontaminate so that it can be reused (waste minimization). The available space and shape of the object generally determines whether to shield the object or shield the worker (portable shield wall). Shielding design for buried items may have to be modular and layered as it is not always possible to determine radiation levels of buried items until they are actually uncovered.

\subsubsection{Civil Structural}

From a safety analysis perspective, structures provide confinement, shielding, a stable anchor for fixed equipment, segregation or isolation, and a controlied environment (dust, humidity, and temperature control) for equipment important to safe operation. Cleanup confinement and shielding are discussed in Sections 7.4.3 and 7.4.4, respectively. Portable equipment is generally self-standing and does not require an anchor for short duration use. This leaves the safety functions of segregation and climate control. Both of these functions can be provided by a tent or, under more severe cases, sheet metal structures. The safety input on choice of structural material will largely depend on integrating factors such as duration of the activity, consequences of structural failure, geographical/meteorological conditions (snow or wind loading), and whether or not an existing structure is involved (D\&D or soil remediation). Consideration should be given to limiting the mass of material for those structures that will be disposed of at the completion of the activity or to ensure the ease of decontamination for those structural components that will be recovered for reuse at another activity. 


\subsubsection{Administrative Controls}

Although not strictly a safety analysis design issue, administrative controls influence both safety analysis and design and are discussed briefly in this paper. When deciding to use administrative controls rather than design features, human factors, detection and response time, staffing levels, activity duration, and hazard or risk consequences must be considered.

As a general rule, design features are preferred over administrative controls. However, as activity durations and hazards decrease, administrative controls are more acceptable to regulators and approval authorities. Consideration should be given both to individual administrative controls and cumulative administrative demands. If considered singularly, most safety issues could be resolved with administrative controls. The difficulty occurs when multiple tasks are assigned to the operator under differing conditions (e.g., in the event of situation a, then refer to control b).

One approach to determining what can be assigned to administrative controls is to develop a list or matrix of operator-assigned actions, the hazards being controlled, and detection/response times needed to mitigate consequences to acceptable levels. This approach will allow singular control selection and provide the cumulative demands needed for human factors discussion within the safety analysis.

\subsection{DESIGN SUMMARY}

Specific design requirements for cleanup activities are absent in the DOE orders. The general requirement applying to cleanup activities is to develop a plan outlining the design and operation of the activity. Also required is a discussion of how this combination (design and operation) will protect the worker, the public, and the environment from undue risk. General guidance is provided that suggests design features be modular, portable, and reusable to the extent safety and operational requirements will allow.

Design features provide the added resource that allows both safety and operational needs to be met. Design features mitigate the potential consequences of hazards that cannot be eliminated or reduced by other means, thus allowing operations to proceed safely. Cleanup activities must be conducted at the site of contamination using design features that have sufficient flexibility to allow them to be used at multiple sites. The alternative to flexible design features is to commit resources used in the design to be discarded at the completion of each cleanup activity. This wasteful design approach would satisfy neither safety nor operation performance objectives.

\subsection{PROPOSAL FOR SHORT-TERM PROJECTS}

Line management is responsible for demonstrating that cleanup activities can be conducted safely with minimal risk to workers, the public, and the environment. However, short-term DOE cleanup projects lack the experience base necessary to establish consensus codes for the entire DOE complex. Without this experience base, DOE cleanup design criteria applicable to all 
DOE contractors would be difficult to develop. The basic safety criteria do allow the development of consistent and applicable design performance objectives from which acceptable designs can be developed and operations can be conducted.

The proposed approach to design is to establish an Operations Development Team consisting of members with expertise in safety, safety analysis, operations, engineering, design, and other specialty expertise where needed. This team should develop performance objectives consistent with the basic safety criteria and the operational requirements of the activity. The team should have an awareness of other activities within the cleanup mission and how the design being developed might provide usefulness in subsequent activities. If designs may prove useful in subsequent activities, consideration should be given to adding the performance objective of portable, modular, and reusable equipment and/or structures. Where activities or portions of activities are unique (used once), simpler, more cost-effective designs should be considered, as long as they provide the needed safety functions.

This approach is likely to take more time than it would if established consensus codes and subsequent design criteria were already in place. The time to acquire these experiences/consensus codes can be shortened if experiences are shared by the various contractors. Coalition groups such as EFCOG and Westinghouse Corporate Maintenance and Operations will help shorten the time needed to gain the experience necessary to reduce design efforts and time while maintaining safety standards.

\subsection{REFERENCES}

Comprehensive Environmental Response, Compensation, and Liability Act of 1980 , 42 U.S.C. 9601 et seq.

Craig, D. K., J. S. Davis, L. G. Lee, P. J. Lein, and P. Hoffman, 1993, Toxic Chemical Hazard Classification and Risk Acceptance Guidelines for Use in DOE Facilities - Draft, SRT-RAM-930011, Westinghouse Savannah River Company, Aiken, South Carolina.

DOE, 1986, Safety of Nuclear Facilities, DOE Order 5480.5, U.S. Department of Energy, Washington, D.C.

DOE, 1988a, Radiation Protection of the Public and Environment, DOE Order 5400.5 , U.S. Department of Energy, Washington, D.C.

DOE, 1998b, Radiation Protection for Occupational Workers, DOE Order 5480.11, U.S. Department of Energy, Washington, D.C.

DOE, 1988c, Radioactive Waste Management, DOE Order 5820.2A, U.S. Department of Energy, Washington, D.C.

DOE, 1989, General Design Criteria, DOE Order 6430.1A, U.S. Department of Energy, Washington, D.C.

National Environmental Policy Act of 1969, 42 U.S.C. 4321 et seq. 


\section{WHC-SA-1917-FP}

Resource Conservation and Recovery Act of 1976, 42 U.S.C. 6901 et seq.

Superfund Amendments and Reauthorization Act of 1986, 42 U.S.C. 11001 et seq.

10 CFR 30, 1993, "Rules of General Applicability to Domestic Licensing of Byproduct Material," Code of Federal Regulations, as amended.

10 CFR 40, 1993, "Domestic Licensing of Source Material, " Code of Federal Regulations, as amended.

10 CFR 70, 1992, "Domestic Licensing of Special Nuclear Material," Code of Federal Regulations, as amended.

40 CFR 302.4, 1993, "Designation, Reportable Quantities, and Notification," Code of Federal Regulations, as amended. 
WHC-SA-1917-FP

\section{DISTRIBUTION}

Number of copies

ONSITE

1

U.S. Department of Energy,

Richland Operations office

RL Public Reading Room H2-52

35

Westinghouse Hanford Company

D. R. Ellingson (30)

H5-37

N. R. Kerr (2)

H4-67

Document Processing and

Distribution

Information Release

L8-15

Administration (2)

H4-17 

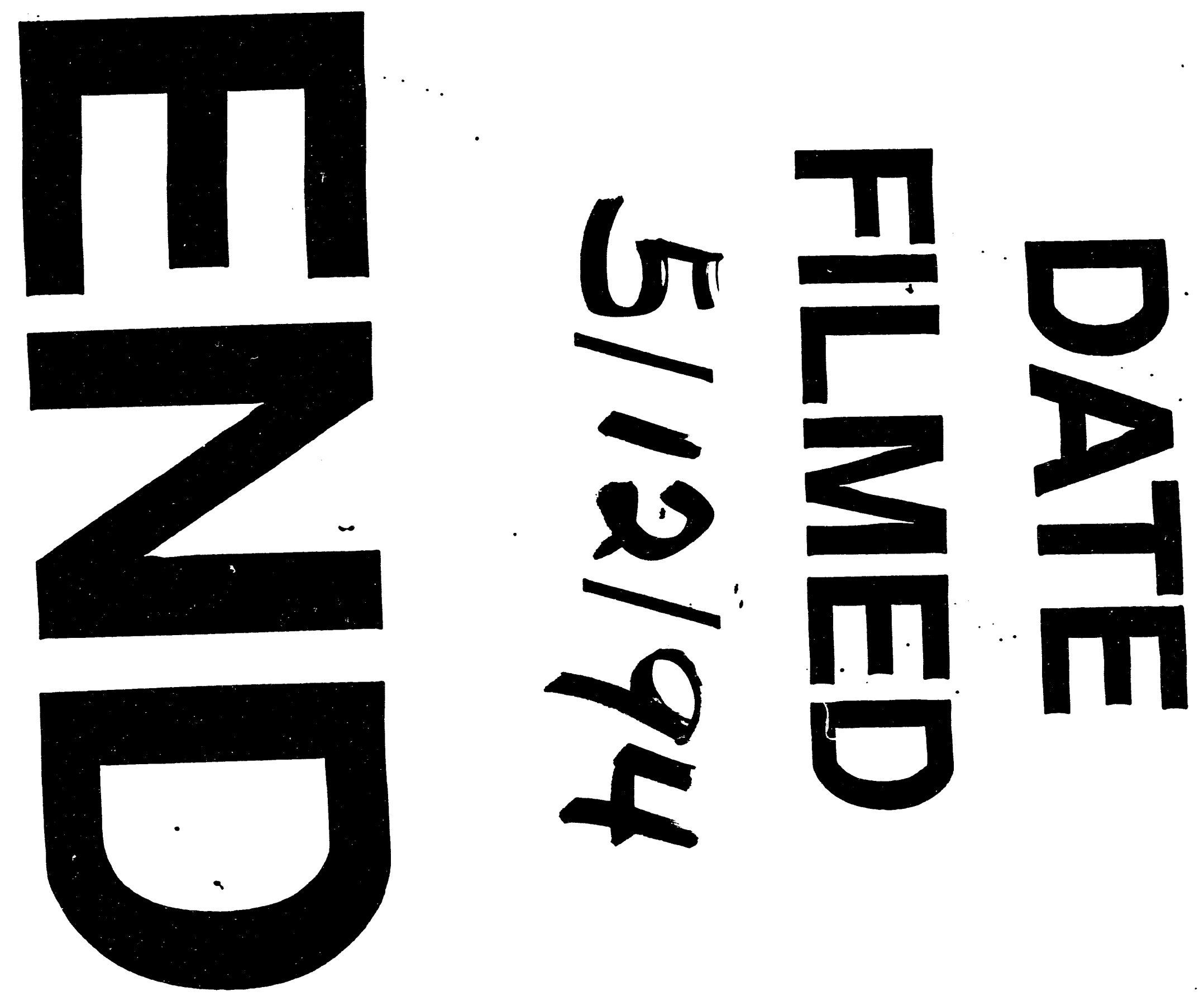
